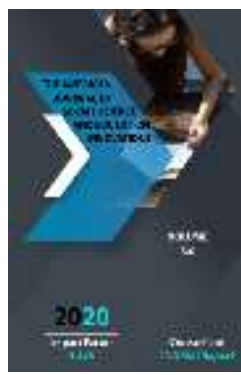

\title{
The Transfer Of The Soul In The Translation Of A Work Of Art
}

\author{
Barnokhon Bakhromkhodjaevna Shamsieva \\ Phd Student, Department Of Translation Studies, Tashkent State University Of Oriental \\ Studies, Tashkent, Republic Of Uzbekistan
}

Journal Website: http://usajournalshub.c om/index,php/tajssei

Copyright: Original content from this work may be used under the terms of the creative commons attributes 4.0 licence.

\section{ABSTRACT}

The reflection of national culture in a work of art and in illuminating its imaginative (association) features in the translated text the reasons for the transfer of psychedelic compounds in the translated text and how the original meaning is transferred to the translated text are considered. There was a shift in meaning when the translated text appeared as a cultural transfer, and when the word originality moved into the field of translation, the original meaning narrowed and a new meaning was added.

\section{KEYWORDS}

Translation theory, translation model, communicative model, transfer, shift of meaning, mental transfer, association

\section{INTRODUCTION}

In the 1990s, "cultural transfer" expanded its scope and began to study the political and cultural ties between the countries of Central and Eastern Europe. The effective result of this method has been chosen as a research topic in a number of social sciences, including history, architecture, art history, and literature. According to M. Espan, the founder of the theory of cultural transfer, the term "cultural transfer" can be used in economic, demographic, psychological, and even intellectual research [14.3]. In his view, the expansion of the scope of scientific research devoted to the cultural area will help to gain a deeper understanding of the mechanism of action of culture. 
In his monograph "Translation and Text Transfer: an essay on the principles of intercultural communication", Anthony discusses the differences and interrelated aspects of translation text and transfer. Унинг таъкидлашича, инглиз тилидаги "Translation(таржима)" хамда "тransfer" сўзлари лотин тилидаги “translatus" ("transferre" феълининг ўтган замон шакли) сўзидан келиб чиққан бўлиб, “олиб ўтиш, кўчириш" маъноларини англатар экан. Ушбу сўзларнинг бир ўзакдан хосил бўлганини билдириб, ўзаро фарқи хақида қуйидагича фикрни илгари суради:“таржима - бу жавобгарлик, трансфер эса қайта тақдим этишди[11.213].

According to LS Barkhudarov's theory, the translation process itself is an interlinguistic transformation. That is, he sees transformation as the replacement, reconstruction, alteration of the meanings of the original text [5.190].

When a language culture is translated into another language, a "shift" of culture occurs. And when a word belonging to a culture is translated into another language, it is accepted by another association. Its meaning in the original text can change its function in the translated text.

If we take the text as belonging to a particular society or situation, and "move" it to another space, the original text will change. Familiar characters vary in degree of alienation. The degree of change of the text being transferred is determined by the conditions under which the text is accepted by society and language. Whether these levels are small or large, the text being transferred loses its value relative to the original language.

Researcher Hu Wenjong studies culture into three groups, the first being all material things in human life, the second group portrays people as a structural culture related to their profession, e.g., legal, political, and so on. Calling the third group a spiritual group, it introduces values, religious insights, and skills related to the value of life. Based on this grouping, researcher Yan Jou distinguishes two types of culture transfer: surface layer transfer and deep layer transfer. Surface layer transfer exemplifies the first and second group cultures because it is relatively easier to understand the culture and give it in translation. The grouping of mental states in the third group is also called deep-layer transfer because of the complexity of the translation [12.143].

In this paper, based on the grouping of researcher Yan Jou, we consider the occurrence of a deep layered culture transfer in the translated text.

\section{THE MAIN FINDINGS AND RESULTS}

Natsume Soseki's "Heart" is known for its inner world, views and feelings. The shift of ideas about the human psyche and character in the text plays an important role in the manifestation of the translated text as a cultural transfer. We came to the conclusion that the main ideological purpose and plot line of the originality, the religious views of the Japanese people, how their psyche is reflected in the text of the Uzbek translation, its transfer will take place at this point. It is known that the translation of literature of other religions has always caused various problems and difficulties for specialists in the field. At the same time, the work of the translator is doubled: at the same time, the translation must fully reflect the content of the original and solve the problem of making the text understandable to the reader [15.8]. It is also important to observe and analyze the extent to which the image of the protagonists - both outwardly and inwardly - reveals their inner world, the extent to which national characteristics are reflected in the translator's 
culture, depending on the translator's knowledge and skills.

The occurrence of a deep layered cultural transfer in the translated text was particularly noticeable in the translation of words related to religious concepts. Because the first idea of the work is to reflect the mental state and worldview of a person of Japanese descent in the work "Heart". This requires that the concepts of mental states be given priority in translation as well. For this reason, the issues of the transfer of units related to religious concepts and images and their transfer in translation were analyzed separately.

It is known that Shintoism and Buddhism are widespread in Japan, where the protagonists live. Shinto, in particular, means to them both history and tradition and the whole way of life. The doctrine of Buddhism expresses doubt and disbelief in the existence of a "supreme creative power" [16.60], and the same belief is advanced in Shinto, which teaches the worship of ancestral spirits and nature [17.83]. In the work "Heart", which we are analyzing, there are a number of examples that prove the above ideas. We will see in the translated text how this situation is manifested in the language of the Uzbek nation, where Islam and culture predominate.

In the following example, we see a shift in meaning.

\section{「天罰だからさ」と伝えて高く笑っ \\ た。 (24-6.)}

"God's punishment! Replied my teacher, and burst out laughing."

May 2013, p. 15)

The phrase天罰だからさ[tenbatsu dakara sa] in the Japanese text literally translates into Uzbek as "the punishment of heaven", and the word天罰[tenbatsu] means "heaven". In the Uzbek nation, we see that the divine power is associated only with the Creator, which is translated in the text as "God's punishment." Although the two languages have the same meaning here, the perception of who or what will be punished in the process of reading the work is different. In other words, the meaning has shifted to the imagination, concretization has taken place.

The reflection of religious-related concepts in the life and thoughts of a person of Japanese descent is, of course, reflected in relation to the imaginations and imaginative possibilities of the writer of that ethnicity. In the translation of the novel, however, the expression of these cases is the most complex process and requires great skill on the part of the translator. In the process of studying this issue, analyzing the transfer of religious concepts, there were cases when Japanese words were translated into Uzbek. In particular, we will consider cases in which words related to religion in the original are given in religious terms in translation.

私は又彼の部屋に聖書を見ました。私はそ れまでに御経の名を度々彼のロから 聞いた覚えがありますが、基督教に就いて は、問われた事も答えられた例もなかった のですから、一寸驚きました。(169-P.)

"In addition, K. I saw the Bible in his room. It surprised me a little bit, because I used to hear a lot of different Buddhist verses from him, but we never talked about Christianity."

\section{(JA, June 2013. p. 137)}

Given that Natsume Soseki's novel The Heart was written in 1914, there are many outdated words in the novel. In the above example, the phrase御経の名[gokei no mei] is one of them, which means "honorable, sacred names" when translated into Uzbek. However, in the 
text of the translation, in the process of reading this sentence, it is as if a person of Uzbek ethnicity is narrating the work (referring to the "Buddhist verse"). This is because the word "verse" refers only to Islam and means "miracle" in Arabic, and the word refers only to a set of complete sentences in the Qur'an, the holy book of Islam.

As mentioned above, translation means transfer. If we analyze the approach to the text as a result in the theory of cultural transfer, we can see that the meaning of the " holy word" is preserved in the original text, and associations about its form and features have shifted in the translated text. Because in the original text it comes only in the sense of "holy names", and the concept of "verse" in the translated text absorbs such notions as "prayer", "recitation".

K にも宗教家らしい様子が、まったく見え なくなりました。(193-p.)

"K, in turn, did not look like a preacher"

(JA.iyul-2013.100-p)

This sentence we are analyzing,Kにも宗教家 らしい様子が、まったく見えなくなりまし た[ K ni mo shūkyōgarashī yōsu ga, mattaku mienaku narimashita] Literally translated as "K's religious status is completely invisible", the original combination of "religious appearance" was translated into Uzbek as "preacher" with literary coloring. The word "preacher" in the Uzbek language means "to explain religious beliefs to the people, the people, propagandist, speaker, orator" [18.175]. In the original宗教家らしい様子 [shūkyōgarashī yōsu] in the phrase "religious appearance" we see that the association of a Buddhist believer is limited to a certain action in the translated text and the transfer is narrowed in meaning.
The word "preacher" is now understood not only as a religious work, but also as a speaker, a speaker on an issue, and for a while it deviates from the original religious concept.

In the next example, we see that the combination of人間らしく [ningen rashiku] in Buddhism is given by the word in Sufi teaching. 私は彼を人間らしくする第一の手段として 、まず異性のそばに彼を座らせる方法を講 じたのです。そうして其所から出る空気に 彼をさらした上、錆び付きかかった彼の血 を新しくようと試みたの

です。(180-p.)

"In order to raise him to the level of a perfect human being, I tried to cleanse his blood from the influence of a woman."

(JA, July 2013. p. 96)

\section{この際彼を人間らしくするのが専一だと考}

えたのです。（180-p.）

"I thought it was important to raise him to the level of a perfect human being."

(JA,

July 2013. p. 96)

人間らしく [ningen rashiku] The combination of "being human".

The concept of "perfect man" given in the translated text as the equivalent of the compound人間らしく[ningen rashiku] is also a concept related to the religion of Islam. Due to the fact that it is the main idea in Sufism, he tried to popularize the phrase "to be like a man." Although the concept of religion in the original is preserved in the translation of the text, the idea is different. That is, the form is different in meaning. This, in turn, reflects the state of religious-cultural transfer.

"The translator can't stick to the words in the work, in a sense he shakes a free pen. This gives him ample opportunity to use the riches of the 
Uzbek literary language, to demonstrate the power of words, to use the words from the vocabulary as a creator and to achieve the goal. The Uzbek image is sometimes even added to the original, to express something a little differently, to take something away from it "[10.15].

人間らしいとか、人間らしくないとかいう 小理屈は殁んど頭の中に残っていませんで した。 (193-p.)

Sophisms such as "to be like a man" or "not to be like a man" have completely disappeared from my mind"

\section{(JA, July 2013. p. 100)}

Above, the compound人間らしい [ningen rashii] is translated as "perfect man". In this example, the phrase人間らしいとか、人間ら しくない[ningen rashii toka, ningen rashikunai] is literally translated as "to be like a man or not to be like a man". Also, the Japanese combination小理屈[ko rikutsu] means "legitimacy", "theoretical", "logical" in Uzbek, and the word "sophism" is used instead in the translated text. The compound人間らし い[ningen rashii], translated as "perfect man" in the above context, is described in this example as "sophism" and we see that the original concept of "being like a man" loses its philosophical color and is transferred to religious-cultural expression in the translated text.

The text of the literary translation reflects all the genre diversity of fiction, it is dominated by emotion and aesthetic taste, and of course the form of expression is also of great importance. Given that artistic and emotional perception is stronger in literature than logical perception of reality, the emotional impact and aesthetic value that the translator exerts on the reader as in the original is higher depending on how the content is presented.
The analysis of the replacement of ordinary words with religious words in the translation of the novel "Heart" is evidence of the above opinion.

故意か自然か、私はそれを出来るだけ切り 詰めた生活をしていた

のです。（131-p.）

When the sentence was literally translated: "Consciously or naturally, I tried to live as detached as possible."

The translation reads: "Whether by wrong belief or by the will of fate, in any case, I have tried to live in isolation from others." (JA, June 2013. p. 122)

In the above example, we understand that in Japan, nature, reliance on the laws of nature, and in the way of life of the Uzbeks, religious views play an important role. That is, the Japanese word自然[shidzen] (naturally) was given the equivalent of the word "destiny", while the word故意[koi] (consciously) was chosen "by faith". So, we can observe the transfer in the sense that the work that is done consciously in the Uzbeks, of course, is based on the criteria of faith, religion.

The following example logically continues the above analysis and ideas:

\section{要するに私は正直な路を歩く積りで、つい} 足を滑らした馬鹿ものでした。(226-p.)

The word正直な [shoujikina] in this sentence is translated into Uzbek as “true, correct”, and正 直な路を歩く means “to walk in the right path". In translation, this sentence,

"It so happened that even though I wanted to be honest, I slipped and became a fool"

(JA, July 2013, p. 114).

That is, the Japanese word正直な [shoujikina] (correct) was translated into Uzbek with the 
word "halal", and the meaning of the simple word in the translation "shifted" to the concept of religion. In the Uzbek nation or in Islam, we can see that the concept of "honest" gives the impression of "the right thing, the right way."

In this way, the specific narration of the reality to the reader led to the religious transfer.

先生の生活に近づきつつありながら、近づ くことのできない私は、先生の頭の中にあ る命の断片として、その墓を私の頭の中に も受け入れた。(38,39-6.)

“No matter how deeply I delved into Master's life, I did not reach the bottom of this connection, but I believed that at least the grave-related memories were part of my life."

May-2013. 20,21- p.)

In Islam, the concept of "faith" implies an unequivocal belief in matters of faith and belief. "I believe" in the text of the translation means that the Uzbek reader came to an agreement without hesitation. When we literally translate the second part of the original text, it means that "the grave in my teacher's mind, which is a part of his life, caught my attention as well." Based on the content of the original text, we see that the meaning increased when the translator added the phrase "grave-related memories" and the Islamic phrase "I believe". This, in turn, clearly reflects the religious-cultural transfer in the text.

In the following example, we can observe the growth of meaning by adding the word religion in the translation:

あなたに会って静かに話す機会を永久に失 った私は、筆を執るすべに慣れないいばか りでなく、貴い時間を惜しむという意味か らして、書きたい事も省かなければなりま せん。（144-6. )
"I don't have the opportunity to tell you everything in a private conversation," he said. I write what I want to write as best I can because I'm not used to holding a pen in my hand. I'm sorry that precious time is running out."

(JA,

June 2013. p. 126)

It is well known that the excessive or useless use of blessings in Islam is characterized by the word waste or waste. The original compound 貴い時間を惜しむ [Tōtoi jikan o oshimu] is translated into Uzbek as "I feel sorry for precious time" and we see in the text of the translation that the Uzbek wastes time with the word "uvol". And we observe that the text of the translation was transferred by assimilating a religious feature, while retaining the meaning of the original.

The image and character of a person are formed on the basis of the views of the nation, its culture. Each of the words related to the character of the protagonist described in the work of art is an important factor in understanding his inner world and forming a vivid picture of him.

Intercultural communication is also reflected in the lexicon of the national language. The translator, on the other hand, can effectively use language units that are purposefully embedded in their national culture. In order to express the real transfer of culture in a way that conforms to the original, the translator is required to have a deep understanding of the other cultural features that come with the play, along with the two national cultures.

In Japanese, there are many words borrowed from English and French, which are written in a special alphabet (katakana). One such word found in the play is “マンオフミーンズ (man of means)", which literally means "rich, 
wealthy man". In the original text, this sentence reads as follows:

家は田舎にありましたけれども、二里ばか り隔った市、一その市には叔父は住んでい たのです。一その市から時々道具屋が懸物 だの、こうろだのを持って、わざわざ父に 見せに来ました。父は一ロに言うと、まあ マンオフミーンズとでも詳したらも好いの でしょう。比較的上品な嗜好を有った田舎 紳士だったのです。（136-p.）

"Our house was in the village, two miles from the town; my uncle lived in this city, from here most of the vendors would bring my father sometimes to show pictures, sometimes incense. In short, my father could be described as "Man of means"'”a sharp-tongued village gentleman."

\section{(JA,}

June-2013.123-p.)

In fact, the text is given as a Japanese transliteration of the English compound "man of means", followed by the meaning that "he was one of the good-natured village nobles." However, in the translation of the work, this English compound is omitted, and its meaning is equated with "sharp-tongued countryman". In the phrase "village wrestler" the Uzbek language has a negative connotation. The play emphasizes the hero's uniqueness. In the original translation of the phrase "man of means" we see that the meaning is transferred in the form of compensation. And again, in this example, the English phrase is given in the Japanese text, and when translated into Uzbek, we can observe a three-way transfer in English-Japanese-Uzbek, assuming the meaning of "village wrestler".

The next example from the novel "The Heart" is an example of a three-culture transfer.

私の知ったものに、夜職人と喧嘩をして、 相手の頭へ下駄で傷を負わせたのがありま した。(135-б.)
"Some of my acquaintances used to go to war with masterovoys in the evenings and beat their heads with their ghettos."

(ja, june 2013, p. 122)

Here the word職人[shokunin] means "craftsman", "master", but as noted in the above sections, the translator uses the word ""Masters"' to give the "breath" of the period in which the work was written. The word is used in Uzbek only to refer to Russian artisans [19.453], and in the Uzbek translation of the novel 職人 [shokunin] we can observe a tripartite cultural transfer in the Russian artisan's perception of the Japanese hero.

The implicit feature in Japanese sentences poses some difficulty in translations into other languages. The following sentence is also an example of this, and the fact that the content of the speech was given by the translator led to the transfer of culture.

「どの位って程ありやしませんわ。まあこ うしてどうかこうか暮らして行かれるだけ よ、あなた。一そりやどうでもいいとして 、あなたはこれからなにか為さらなくっち や本当にいけませんよ。先生のようにごろ ごろばかりしていちゃ. . . . 」(44-p.)

"My financial situation depends on my husband's help, we don't have enough," he said. But here we are, still a couple living as twin bulls. "My financial situation depends on my husband's help, we don't have enough," he said. But here we are, still a couple living as twin bulls."

(JA, May 2013. p. 26)

The phrase "my financial situation depends on the help of my spouse" does not exist in the original text, and it is not surprising that this phrase was added in accordance with the customs of Japanese and Uzbek culture. In the 
original text, どうかこうか暮らして行かれる だけよ [Do ka ko ka kurashite ika reru dake yo] means "We live together" and the word is translated into Uzbek using a common proverb. In the original Uzbek phrase "we have nothing, we barely live", when the phrase "married couple bull" is used, the notion of "married couple together" is preserved, but "married couple" The phrase "bull" basically means "to shake a household together."

\section{CONCLUSION}

As a work of art is translated from one language to another, the ideas of the original, the factors that reflect the worldview of the nation are also reflected in the text of the translation. As the translation takes place, he will "follow" the transfer. It is the responsibility of the translator to fully convey the content and idea of the original. Even when the translation is done by a skilled interpreter, a certain sense of transfer is observed. However, among the examples we analyzed above, we also observed transfers that occurred through erroneous translation. If we look at the work of art as a source of expression of the worldview, ideas and goals of a nation, we need to take a responsible approach to translation.

We believe that the diversity of interethnic ideas, the diversity of beliefs is a key factor in the transfer of concepts related to spiritual culture. In the course of the analysis, a transfer was observed in sentences that reflected the predominance of the laws of nature in Japanese religious culture. The fact that even simple words are used in religious terms shows that the criteria of moral values, which form the basis of religion, play an important role in the life of Uzbeks. In the description of the image of the hero, it was found that the Uzbek text is more common than the Japanese text. The shift in perceptions of the human psyche and character in the text played an important role in the manifestation of the translated text as a cultural transfer. In the text of the translation we conclude that in the process of transfer through the imagination of the mediator-translator the reader's perception of the original text is formed.

The analysis of the three-cultural transfer phenomenon encountered in the translated text was of particular interest. To see this method in other translations as well, we think that the study of its mechanisms requires more separate research.

\section{REFERENCES}

1. Natsume Soseki (1952). Kokoro. Shinchousha, Japan, 1952. 260 p.

2. Natsume Soseki (2013). Heart. World literature, № 5(192), P. 7-34.

3. Natsume Soseki (2013). Heart. World literature, № 6(193), P. 115-139.

4. Natsume Soseki (2013). Heart. World literature, № 7(194), P. 94-122.

5. Barhudarov L. S. (1975). Language and translation. Moscow: Mejdunarodnie otnosheniya - International relationships Publ. P. 240. (In Russian)

6. Durdureanu I.I. (4. 2011) Translation of Cultural Terms: Possible or Impossible?, JoLIE. P. 23-26.

7. Garbovskiy N. K.(2007). Teoriya perevoda [Translation theory], Moscow, Moscow University Publ. P. 544. (In Russian)

8. Hanada Mariko (2009). The Cultural Transfer in Anime Translation, Vol. 13, No. 2, April, USA. P.15-21.

9. Lobacheva D.V. (8. 2010). Cultural transfer: definition, structure, role in the system of literary interactions Vestnik .(98)edition. P. 23-27p. (In Russian)

10. Olim S. (1991). Ibrahim Gofurov's interpretation of "Doomsday" 
Translation problems. Tashkent. P.12-

23

11. Pym Anthony (2010). Translation and

Text Transfer: an essay on the principles of intercultural communication, Tarragona: Intercultural Studies Group. P.213.

12. Yan Zhou (July 2008). The Impact of Cultural Transfer on Cross-cultural Communication//Asian Social Science, Vol.4, No.7. -P. 142-146

13. Explanatory dictionary of the Uzbek language, (1981).1st volume, Moscow. P. 631.

14. Espagne M.(1999). Franco-German cultural transfers. Paris. P. 3.

15. Shirinova R. H. (2002). Some principles of re-creation of religious realities in literary translation.dissertation for the degree of candidate of philological sciences. Tashkent. P. 8.

16. Theology (2004). Tashkent, Mehnat. P 60.

17. Theology (2004). Tahkent, Mehnat. P 83.

18. Explanatory dictionary of the uzbek language (1981). 1st chapter. Moscow. P. 175

19. Pre-revolutionary Russian craftsman. Explanatory dictionary of the Uzbek 